\title{
MENILIK KEGIATAN PRAMUKA YANG BERPERAN DALAM MENANAMKAN SIFAT KEBANGSAAN PADA GENERASI MUDA MESKIPUN DI ERA PANDEMI (STUDI KASUS DI KWARTIR CABANG KOTA CIMAHI)
}

\author{
Fadlilah Jufany Mustika ${ }^{1}$, Supriyono $^{2}$, dan Dadi Mulyadi ${ }^{3}$
}

Indonesian Language and Literature Education, Universitas Pendidikan Indonesia

\begin{tabular}{l}
\hline Info Artikel \\
\hline Sejarah Artikel: \\
Disubmit: April 2021 \\
Direvisi: Mei 2021 \\
Diterima: Mei 2021 \\
\hline \\
\hline Keywords: \\
Scout; Pancasila; young \\
generation; globalization; \\
covid-19
\end{tabular}

\begin{abstract}
Abstrak
Penelitian ini bertujuan untuk (1) sikap berbangsa yang dapat diterapkan dari kegiatan pramuka, (2) nilai-nilai Pancasila yang diimplementasikan dari berkegiata pramuka, (3) menanamkan jiwa nasionalisme dan kebangsaan, (4) menumbuhkan rasa cinta tanah air, (5) mengetahui hal positif apa saja yang didapatkan dari kegiatan pramuka, dan (5) pengaruh covid-19 dalam pelaksanaan kegiatan pramuka. Untuk itu, dilakukan sebuah penelitian dengan pendekatan kuantitatif dengan membagikan kuisioner (survei) kepada anggota pramuka di pangkalan Kwartir Cabang Kota Cimahi dan melaporkan hasilnya dengan deskriptif. Kepramukaan dianggap penting dalam membentuk generasi bangsa agar memiliki sikap cinta tanah air. Melihat dari tujuannya, kegiatan pramuka bertujuan untuk meningkatkan sumber daya kaum muda Indonesia dan meningkatkan rasa nasionalisme yang pada era globalisasi seperti saat ini terasa telah memudar. Pramuka mengajarkan setiap anggotanya untuk selalu patuh terhadap segala peraturan yang berlaku.
\end{abstract}

\begin{abstract}
This research aims to (1) national attitudes that can be applied from scouting activities, (2) Pancasila values that are implemented from scouting activities, (3) instill a spirit of nationalism and nationality, (4) foster a sense of love for the country, (5) see what positive things are obtained from scouting activities, and (5) the influence of covid-19 in the implementation of scouting activities. For this reason, a study with a quantitative approach was carried out by distributing questionnaires (surveys) to scout members at the Cimahi City Branch Kwartir base and reporting the results descriptively. Scouting is important in shaping a nation so that it has an attitude of love for the country. Looking at the community, scouting activities aim to increase the resources of young Indonesians and increase the sense of nationalism which in the current era of globalization feels faded. Scouts teach each member to always obey all applicable regulations.
\end{abstract}

(C) 2021 Universitas Negeri Semarang 


\section{PENDAHULUAN}

Berkaitan dengan era globalisasi yang berkembang di Indonesia, teknologi pun kian canggih, dan berbagai macam kebudayaan dapat masuk dan diterima di Indonesia. Hal itu pun berpengaruh pada generasi muda saat ini. Banyaknya budaya yang masuk ke Indonesia membuat pemuda lebih banyak mengenal budaya asing dibandingkan budaya negara sendiri. Hal itu pun berdampak pada jiwa nasionalisme para pemuda yang kian memudar.

Dalam hal ini, kegiatan yang
mengutamakan dan berlandaskan pada
nasionalisme yang memiliki tujuan untuk
meningkatkan rasa cinta tanah air dan jiwa
kebangsaan sangat dibutuhkan. Kegiatan yang
paling terlihat dalam mewujudkan hal tersebut
saat ini adalah paskibra dan pramuka.

Kepramukaan merupakan suatu proses pendidikan di luar lingkungan sekolah dan juga keluarga yang dikemas dengan menyajikan banyak aktivitas menarik, sehat, terarah, teratur, praktis, dan menyenangkan yang dilakukan di alam terbuka dengan mengutamakan prinsip dan metode dasar kepramukaan. Kepramukaan mempunyai target akhir yakni terciptanya pembentukan watak, akhlak, dan budi pekerti luhur. Kepramukaan adalah sistem pendidikan kepanduan yang disepadankan dengan kepentingan, keadaan, dan perkembangan masyarakat serta bangsa Indonesia.

Kepramukaan dianggap penting dalam membentuk generasi bangsa agar memiliki sikap cinta tanah air. Berdasarkan pada tujuannya, kegiatan pramuka bertujuan untuk meningkatkan sumber daya manusia khususnya pada kaum muda Indonesia serta meningkatkan rasa nasionalisme yang terasa semakin memudar pada era globalisasi seperti saat ini. Kesadaran bela negara harus ditanamkan sebagai dasar pembentuk bangsa yang kuat. Selain itu, melalui pramuka generasi muda akan lebih mengetahui dan mengimplementasikan nilai-nilai pancasila dalam kehidupannya dan akan senantiasa memiliki rasa cinta tanah air yang terwujud melalui setiap kegiatan yang diselenggarakan oleh kepramukaan.

Dalam menyikapi perubahan percepatan gaya hidup serta perilaku siswa pada usia anak dan menjelang remaja, dibutuhkan wadah untuk mengembangkan potensi yang dimilikinya dan sekaligus menjadi sarana pengembangan bakat dengan disertai penanaman sikap nasionalisme dalam dirinya (Nainggolan: 89). Melalui pernyataan tersebut dapat diketahui bahwa Pramuka merupakan wadah yang tepat untuk dijadikan sebagai solusi kegiatan alternatif untuk mewujudkannya pengembangan potensi disertai jiwa berbangsa.

Melihat dari persoalan yang terjadi saat ini, berlangsungnya kegiatan pramuka sangat dipertanyakan. Pramuka dikenal sebagai lembaga yang selalu melaksankaan kegiatan di alam bebas dan di tengah masyarakat. Namun, akankah pramuka tetap melangsungkan kegiatan di era pandemi covid-19 seperti sekarang ini? Sudah menjadi perbincangan sejak awal kemunculannya, covid-19 membuat banyak kegiatan menjadi terganggu. Mulai dari sekolah, pariwisata, dan membuat banyaknya pekerjaan terhambat.

Hal tersebut membuat penulis ingin mengetahui dampak yang ditimbulkan dari menjalarnya covid-19. Melalui penelitian ini, akan disampaikan bagaimana minat anggota terhadap pramuka di era pandemi dan hambatan yang terjadi dalam berkegiatan di era pandemi covid-19 di Kota Cimahi.

Selain itu, hal utama yang akan dikaji dalam penelitian ini yakni sikap berbangsa yang dapat diterapkan dari kegiatan pramuka. Mengingat pramuka selalu mengaitkan setiap kegiatannya dengan hal kenegaraan, maka membuat penulis ingin mengetahui kebenaran bahwa pramuka memang membuat anggotanya dapat mengimplementasikan nilai-nilai pancasila, memiliki rasa cinta terhadap tanah air, menjadi warga negara yang baik, dan juga lebih menilik mengenai hal positif apa saja yang didapatkan melalui berkegiatan pramuka. 


\section{METODE}

Dalam penelitian ini, penulis menggunakan metode pendekatan kuantitatif. Penelitian dengan metode kuantitatif adalah penelitian yang dilakukan dengan menguji, menjelaskan, dan menetapkan hubungan antar variabel dengan membagi permasalahan menjadi beberapa bagian yang dapat diukur, dinyatakan ataudijelaskan dalam bentuk angka. Penelitian dengan pendekatan kuantitatif umumnya memerlukan instrumen atau alat yang berguna untuk mengumpulkan data sehingga menghasilkan data berupa numerik atau angka. Selain menggunakan metode pendekatan kuantitatif, penelitian ini juga menggunakan pendekatan kualitatif dan disempurnakan dengan metode studi pustaka. Metode kualitatif sendiri yakni penelitian yang menghasilkan data deskriptif berupa kata-kata tertulis dari orangorang serta perilaku yang diamati. Sedangkan metode dengan studi pustaka yakni metode penelitian dengan mengumpulkan berbagai macam rujukan yang kemudian akan dijadikan sebagai referensi penulisan dan penguat penelitian.

Penelitian ini dilakukan pada tanggal 11 Maret 2021 dengan membagikan kuesioner berupa survei yang memiliki soal berjumlah 14 soal. Hasil dari survei tersebut kemudian dianalisis dan dibuat dalam bentuk deskriptif.

Adapun tahap-tahap yang dilakukan dalam penelitian ini, yaitu (1) membagikan kuisioner pada tanggal 11 - 12 Maret 2021 yang dibuat dengan google form. Kuisioner ini dibagikan kepada seluruh pangkalan yang ada di wilayah kota Cimahi dan telah mencapai tingkat penegak atau seusia dengan siswa SMA, (2) kuisisoner diisi oleh para responden dengan memasukan nama lengkap, alamat email, usia, dan juga pangkalan asalnya, (3) setelah terkumpul semua pada batas waktu tanggal 13 Maret 2021, dilakukan analisis mengenai hasil dari kuisioner tersebut.

Berdasarkan proses yang telah dilakukan, tercacat ada 34 responden yang bersedia untuk mengisi kuisioner penelitian dari 13 pangkalan dengan rentang usia $15-20$ tahun dan dipastikan masih aktif menjadi anggota pramuka. Adapun 11 pertanyaan yang diajukan oleh peneliti, diantaranya:

1. Apakah mengikuti kegiatan pramuka atas dasar kemauan sendiri?

2. Alasan tertarik untuk bergabung dengan pramuka

3. Setujukah Anda jika kegiatan pramuka dapat menumbuhkan rasa cinta tanah air?

4. Setujukah Anda jika kegiatan pramuka dapat menanamkan nilai-nilai Pancasila?

5. Mengemukakan alasan mengapa memilik jawaban sebelumnya

6. Apa sajakah hal positif yang Anda dapatkan dalam berkegiatan pramuka?

7. Apakah dengan berkegiatan pramuka dapat membuat Anda menjadi warga negara yang baik?

8. Mengemukakan alasan mengapa memilik jawaban sebelumnya

9. Apakah covid-19 berdampak besar bagi keberlangsungan kegiatan pramuka?

10. Apakah covid-19 dapat melunturkan semangat Anda untuk tetap berkegiatan pramuka?

11. Mengemukakan alasan mengapa memilik jawaban sebelumnya

Setelah data terkumpul, peneliti kemudian mengkaji prosedur penelitian yang terdiri dari beberapa tahap sebagai berikut: (1) Menganalisis hasil kuisioner, (2) membuat laporan penelitian, dan (3) membentuknya dalam jurnal penelitian.

Laporan penelitian dan penyusunan jurnal merupakan tahap akhir penelitian dari serangkaian proses. Hal itu dilakukan setelah menganalisis, merumuskan, dan menarik kesimpulan dalam tahap penyampaian data. Kemudian setelah semua selesai, laporan masih harus dikonsultasikan dengan pembimbing mata kuliah.

\section{PEMB AHASAN}

\section{Ketertarikan Terhadap Pramuka}

Dalam (KBBI) dikemukakan pengertian tertarik, yakni suatu sikap suka, senang; perasaan menaruh minat terhadap sesuatu. Maka dapat dijelaskan bahwa ketertarikan terhadap Pramuka yakni sikap suka, senang, dan menaruh minat untuk mengikuti kegiatan yang diselenggarakan 
dalam Pramuka. Pada pertanyaan di kuisioner pertama yang disediakan mengenai latar belakang mengikuti pramuka, semuanya menyatakan bahwa mengikuti pramuka atas dasar keinginan sendiri. Para responden menyatakan bahwa tidak ada paksaan ataupun ikut-ikutan dengan orang lain dan tentu masingmasing memiliki alasan.

Melalui pertanyaan di kuisioner kedua mengenai alasan bergabung dengan pramuka, para responden menyertakan berbagai alasan. Sebagian besar menyatakan ingin menambah wawasan, keahlian, dan juga karena diajarkan mencintai alam, selebihnya menyertakan alasan karena kegiatan yang dikemas dengan asik sehigga dapat membuat tertarik. Pramuka memang dikenal dengan organisasi yang memiliki banyak kegiatan yang sangat menarik tetapi juga mengedukasi para anggotanya.

\section{Hal-Hal Positif yang Didapatkan dalam Kegiatan Pramuka}

Dalam pertanyaan pada kuisioner berikutnya mengenai hal positif mengikuti kegiatan Pramuka. Responden merespon dengan berbagai jawaban dan ditemukan beberapa jawaban yang juga dapat ditarik kesimpulan.

Adapun hal positif yang didapatkan dalam kegiatan Pramuka, yaitu 1) membuat pribadi lebih mandiri dan disiplin. Hal ini dibuktikan karena kegiatan pramuka cenderung selalu dilakukan di alam dan jauh dari sanak keluarga. Oleh karena itu, jiwa mandiri dan disiplin tentu sangat dibutuhkan untuk dapat bertahan hidup dan melatih diri;2) melatih jiwa kepemimpinan. Pramuka merupakan sebuah organisasi di mana tentu anggotanya dilatih untuk dapat memimpin dan memiliki keahlian dalam berorganisasi; 3) menanamkan sikap kebersamaan dan saling membantu. Pramuka merupakan organisasi yang dikenal memiliki solidaritas yang sangat kuat. Seperti hakikatnya manusia yang tidak bisa hidup sendiri dan bergantung kepada orang lain, Pramuka mengajarkan para anggotanya untuk bisa hidup dalam kebersamaan dan selalu siap membantu dalam segala tantangan; 4) melatih untuk hidup dan mencintai alam. Dalam Dassa Dharma No. 2 yang berbunyi "Cinta alam dan kasih sayang sesame manusia", dapat diartikan bahwa anggota Pramuka tentu dididik untuk memiliki rasa cinta terhadap alam dengan cara menjaga dan melestarikan alam itu sendiri; dan 5) dapat menumbuhkan sikap toleransi, rasa cinta tanah air, dan integrasi. Tak bisa dipungkiri bahwa Pramuka juga dikenal sebagai organisasi yang erat kaitannya dengan kecintaan terhadap tanah air Indonesia. Dapat dilihat dari atribut yang selalu dipakainya itu menunjukkan bahwa para anggota sangat mencintai bangsanya.

\section{Nilai-Nilai Pancasila yang Diimplementasikan}

Melalui kuisioner yang telah disediakan, semua responden setuju bahwa dengan mengikuti kegiatan pramuka, banyak sekali nilainilai Pancasila yang dipelajari dan diimplementasikan.

Dalam kepramukaan, tentunya mengutamakan nilai Pancasila sebagai landasannya. Oleh karena itu, tentu saja setiap anggota harus memahami dan melakukan segala tindakan dengan berlandaskan Pancasila.

Dalam pramuka sendiri dikenal dengan kode kehormatannya, yakni Tri Satya (tiga janji Pramuka Indonesia yang harus dilakukan) dan Dasa Dharma (pedoman anggota Pramuka Indonesia dalam bersikap). Kedua kode kehormatan tersebut tentunya dibuat berlandaskan Pancasila.

Contohnya pada Dasa Dharma Pramuka. Kode kehormatan ini sejatinya adalah perwujudan dari nilai-nilai yang terkandung dalam Pancasila. Dari sinilah pendidikan kepramukaan dianggap sebagai salah satu pendidikan nasional yang sangat penting juga bagian dari wujud perjuangan bangsa Indonesia. Meskipun Gerakan Pramuka termasuk organisasi ekstrakurikuler di dunia pendidikan yang bersifat nonformal, tetapi Gerakan Pramuka merupakan wujud dari usaha membantu pemerintah dan masyarakat dalam membangun generasi yang berkepribadian sesuai dengan pedoman hidup bangsa Indonesia, yakni Pancasila.

Adapun nilai-nilai Pancasila yang dapat ditumbuhkan, dilatih, dan diimplementasikan 
melalui kegiatan Pramuka, diantaranya nilai ketuhanan, kemanusiaan, persatuan, kerakyatan dan keadilan yang juga terkandung dalam Dasa Dharma. Selain itu, dalam Tri Satya nomor tiga terdapat kalimat yang berbunyi "Mengamalkan Pancasila", sebagai bukti bahwa setiap anggota pramuka wajib hukumnya untuk mengimplementasikan nilai Pancasila.

\section{Menjadikan Anggota sebagai Warga Negara yang B aik}

Dalam kuisioner yang telah disediakan pertanyaan yag berkaitan dengan kegiatan Pramuka yang mengajarkan untuk menjadi warga negara yang baik. Dari 34 responden, 33 orang menjawab ya dan 1 orang menjawab mungkin. Adapun analisis penjelasan para responden yang menjawab ya, yakni Pramuka selalu mengajarkan untuk bersikap dan berperilaku sesuai dengan Pancasila. Salah satu syarat menjadi warga negara yang baik, yaitu mematuhi peraturan pemerintah, negara, dsb. begitu juga dengan anggota pramuka yang selalu mengamalkannya karena juga memiliki kaitan erat dengan pemerintahan.

Dalam hasil penelitian, terdapat satu responden yang menjawab mungkin dengan alasan kembali kepada diri masing-masing. Melalui pernyataan tersebut, dapat dianalisis bahwa Pramuka memang mengajak dan mengajarkan untuk cinta terhadap tanah air, tetapi itu semua dapat diimplementasikan tergantung pribadi anggotanya. Ada kalanya anggota Pramuka tidak menerapkan apa yang diajarkan, tetapi tetap mengakui dirinya sebagai Pramuka. Jadi, penerapan pembelajaran dari Pramuka itu tergantung pribadi masing-masing.

\section{Pengaruh Covid-19 Terhadap Kegiatan Pramuka}

Berdasarkan hasil survei mengenai kegiatan Pramuka di era pandemic, didapatkan bahwa keiatan banyak terkendala. Covid-19 ini memang sangat berdampat bagi semua jenis kegiatan, salah satunya Pramuka. terlebih Pramuka dikenal dengan kegiatannya yang selalu berada di alam dan di tengah masyarakat. Pandemic ini membuat kegiatan Pramuka menjadi tidak kondusif. Namun, dari survei yang telah dilakukan, 33 dari 34 orang responden menatakan bahwa pandemi ini tidak membawa pengaruh dan tidak menyurutkan semangat untuk tetap berkegiatan Pramuka meskipun dengan berkegiatan dalam jaringan (daring).

\section{SIMPULAN}

Kepramukaan merupakan suatu proses pendidikan kepanduan yang dilakukan di luar lingkungan sekolah dan keluarga yang dikemas dengan menyajikan berbagai kegiatan menarik, terarah, sehat, teratur, praktis, dan menyenangkan yang dilakukan di alam terbuka dengan mengutamakan prinsip dan metode dasar kepramukaan. Kepramukaan memiliki target akhir yakni terciptanya pembentukan watak, akhlak, dan budi pekerti luhur. Kepramukaan merupakan sistem pendidikan kepanduan yang disesuaikan dengan kepentingan, keadaan, dan perkembangan masyarakat serta perkembangan bangsa Indonesia. Kepramukaan dianggap penting dalam membentuk dan mencetak generasi bangsa agar memiliki sikap cinta tanah air.

Berdasarkan penelitian yang telah dilakukan, dapat ditarik kesimpulan mengenai banyaknya hal positif yang dapat diimplementasikan dalam kegiatan Pramuka. Kesimpulan ini diambil berdasarkan hasil survei, yakni 1) para anggota Pramuka dengan senang hati dan tanpa ada paksaan atau ikut-ikutan dalam melakukan kegiatan pramuka. Hal ini berarti bahwa para responden telah mengetahui bahwa dalam kegiatan Pramuka banyak hal positif yang dapat diambil, dipelajari, dan diimplementasikan; 2) membuat para anggotanya belajar menjadi warga negara yang baik. Dalam Dasa Dharma No. 4 yang berbunyi "Patuh dan Suka Bermusyawarah" dapat diartikan bahwa Pramuka mengajarkan setiap anggotanya untuk selalu patuh terhadap segala peraturan yang berlaku; 3) menanamkan rasa cinta tanah air; 4) pengimplementasian nilai-nilai 
Pancasila dalam kegiatan Pramuka. dalam setiap pergerakan kegiatannya, Pramuka selalu memiliki landasan terhadap Pancasila dengan dibuktikan melalui kode kehormatan Tri Satya dan Dasa Dharma; 5) pandemi covid-19 sangat berpengaruh bagi keberlangsungan kegiatan pramuka karena ruang lingkup Pramuka ada di alam dan di tengah masyarakat. Namun, hal itu tidak menyurutkan semangat anggotanya untuk tetap berkegiatan meskipun dilaksanakan dengan daring (dalam jaringan).

\section{DAFTAR PUSTAKA}

Badan Pengembangan Bahasa dan Perbukuan. 2020. Kamus Besar Bahasa Indonesia. Jakarta: Kementrian Pendidikan dan Kebudayaan Republik Indonesia.

Kibriya, A. L. 2019. Nilai Sosial Dan Moral Dalam Teks Drama Petag Ditaman Karya Iwan Simatupang Melalui Pendekatan Struktural. Konfliks: 6(2), $9-10$.

Kristono, N., G. Hartono W, dan H. Nuha A. 2019. Implementasi Nilai-Nilai Pancasila Dalam Kegiatan Kepramukaan (Studi Kasus
Madrasah Aliyah Al-Asror Semarang). Harmony: 4(1), 16 - 17.

Laksono, F. dan A. W. 2018. Pengaruh Ekstrakurikuler Pramuka Terhadap Kedisiplinan Dan Kemandirian Siswa. Joyful Learning Journal: 7(1), $64-66$.

Listiyono, T. 2013. Implementasi Trisatya Gerakan Pramuka Dalam Menumbuhkan Sikap Bela Negara Bagi Siswa Kelas Vii Sekolah Menengah Pertama Negeri 2 Gatak Tahun Pelajaran 2012/2013. Naskah Publikasi Universitas Muhammadiyah Surakarta.

Mawarni, G. Agatri. 2017. Menumbuhkan Sikap Cinta Tanah Air Melalui Ekstrakulikuer Pramuka Demi Membentuk Generasi Penerus Bangsa. (diakses pada tanggal 14 Maret 2020 melalui http://pramukapgsd16.blogspot.com/20/ $17 / 12 /$ menumbuhkan-sikap-cinta-tanahair.html)

Taubah, M dan U. Chasanah. 2018. Peranan gerakan pramuka dalam menanamkan sikap nasionalisme di madrasah ibtidaiyah. Elementary: 6(2), $338-339$. 